\title{
Understanding Customer Motivation to Share Information in Social Commerce
}

\author{
Yen-Hao Hsieh, National Formosa University, Taiwan \\ Ya-Ting Lo, Tamkang University, Taiwan
}

\begin{abstract}
The gradual emergence of social commerce is enhancing the development of businesses. The opinions exchanged and information shared by each consumer in the community affects consumers' purchasing decisions and participation behaviors. This study established a consumer information sharing model in social commerce based on the theories of social exchange and communication ecology. Data were collected from 204 respondents, and PLS technique was used to analyze the data. The results indicated that reciprocity and community participation exhibited a significantly positive effect on information sharing. Reciprocity and community participation also had partial mediation effects on the consumer-community and consumer-platform relationships.
\end{abstract}

\section{KEYWORDS}

Communication Ecology, Community Participation, Customer Relationship, Information Sharing, Reciprocity, Social Commerce, Social Exchange

\section{INTRODUCTION}

The gradual emergence of social commerce is enhancing the development of business platforms that combine community communication and product transactions. Group buying websites (e.g., Groupon Reserve, LivingSocial Gourmet, GOMAJI, and Gilt City) are one such type of platform and product review platforms (e.g., Yelp and TripAdvisor) are another. These social media platforms bring together consumers that have the same purchasing needs and product purchasing experiences. Consumers can discuss the characteristics, use experience, and shopping experience concerning a certain product or brand through the platforms (Cheng \& Fang, 2015). These platforms attract consumers and encourage them to share their personal opinions and experiences; other consumers can browse the content, which helps them resolve their doubts about a product.

Social commerce combines the concepts of community and e-commerce. Consumers can score, comment, and recommend products. Enterprises establish trust relationships through interactions with consumers (Esmaeili, Mutallebi, Mardani, \& Golpayegani, 2015; Gecti \& Zengin, 2013; Habibi et al., 2014) and improve consumers' sense of belonging through experience exchanges and information sharing (Laroche, Habibi, Richard, \& Sankaranarayanan, 2012; Qin \& Kong, 2015). Consumers who identify with and join a community tend to be willing to share personal experiences with other community members (Hajli et al., 2017; Khan, 2017; Liang \& Turban, 2011; Zhang, Guo, Hu, \& Liu, 2017). In the United States, $70 \%$ of online shoppers trust the recommendations of their relatives and 
friends; $46 \%$ of online shoppers trust the online reviews of other consumers (Qin \& Kong, 2015). Therefore, the recommendations of relatives and friends, the experience sharing of netizens, and the grading results of social commerce profoundly affect consumer purchasing decisions (Hajli \& Sims, 2015; Phillips, 2011).

Consumers usually make purchasing decisions on the basis of information collection, product functions, and price comparisons (Maria \& Finotto, 2008). Cheng \& Fang (2015) demonstrated that $77 \%$ of consumers read blog content before purchasing products and $74 \%$ of consumers search online consumer reviews. Chen \& Shen (2015) proposed that approximately $83 \%$ of consumers share shopping information with netizens and nearly $67 \%$ of consumers make purchasing decisions on the basis of the recommendations of netizens. In addition, nearly $85 \%$ of consumers, whether online or in physical stores, browse the personal experiences shared by consumers online (Liu, Cheung, \& Lee, 2016). For products exhibiting unclear functions or high unit prices, consumers may have anxiety and doubts about these products and consequently never purchase them.

If consumers have reviewed the detailed product descriptions on official websites or in marketing advertisements and still have doubts about the products, they then tend to accept the personal experiences shared by other consumers, considering those use experiences to be real and objective (Qin \& Kong, 2015). Therefore, a tremendous number of sponsored posts have become common on social media platforms. Enterprises use the popularity and reputations of bloggers and YouTubers to market products or brands (Raetzsch, 2015). However, most of the articles or videos shared by bloggers and YouTubers directly refer to the official product introduction rather than including comments from the perspective of consumers and also lack explanations of product flaws and specific suggestions. These inadequacies lower consumers' trust in bloggers and YouTubers and lead consumers to believe that the information is being provided for commercial purposes and is not objective (Williams \& Hodges, 2016).

By undertaking product and brand marketing through the community, enterprises use word of mouth to effectively deliver product or brand in-formation (Jiang, Luo, \& Kulemeka, 2016; Habibi et al., 2016). Social commerce emphasizes the importance of the community. The opinions exchanged and information shared by each consumer in the community affects the purchasing decisions and participation behaviors of other consumers (Hajli et al., 2017). Therefore, designing a friendly platform for community social commerce that induces consumers to spontaneously share their personal experiences is vital. Enterprises should determine whether and how external stimulation (e.g., community communication and consumption contexts) or internal factors (e.g., consumers' willingness and attitudes) directly or indirectly affect consumers' information sharing behavior (Wu \& Lin, 2016). Therefore, enterprises should explore the latent variables, predispositions, and factors that directly or indirectly affect consumers' information sharing behavior.

In light of the aforementioned research background and motivation, this study proposed the following research question: what are the essential factors affecting consumers' sharing of personal information in social commerce? To solve the research problem, this study established its primary purposes as creating a model of consumer information sharing in social commerce and exploring the factors that affect consumers' information sharing on social commerce platforms. This study investigated consumers' information sharing behavior in social commerce to determine the key factors and to establish a model of consumers' information sharing behavior to assist enterprises to effectively grasp consumers' motivation for participating in information sharing. By encouraging consumers to actively share product information and comments, the visibility of products and brands can be increased, thereby increasing the sales of products.

The remainder of the article is organized as follows. First, we discuss the previous research in the areas of social commerce, social exchange theory and customer relationship. Next, we introduce the research model and hypotheses development. Then, we detail data analysis and research results. Finally, we provide a discussion of the importance, contributions, and implications for researchers and managers. We conclude with a robust future research agenda. 


\section{THEORETICAL FOUNDATION}

\subsection{Social Commerce}

Over recent years, social media has played an important role in our daily life that enables people to interact and deliver information conveniently. As social media becomes popular, enterprises also attempt to figure out how to adopt social media to attract and engage their consumers. Enterprises apply technical characteristics of social media as business tactics including online collaboration, social support and information sharing (Choi et al., 2020; Chung et al., 2020). Sivarajah et al. (2020) noted that enterprises can employ social media analytics for better understanding consumer needs and improving productivity and efficiency in order to achieve business sustainability. Besides, enterprises also effectively investigate potential consumers and their profiles to search business opportunities by using social media-based approaches (Choi et al., 2020). Accordingly, social media has been adopted by enterprises to enhance interactions with consumers and build a virtual and collaborative environment (Yoo et al., 2015).

Social commerce emerged in 2005 and is considered a novel concept in e-commerce development, combining social media and e-commerce (Hajli, 2013; Hajli, Shanmugam, Powell, \& Love, 2015). By combining the unilateral functions of providing product information and enabling shopping transactions, e-commerce websites provide opportunities for consumers to exchange opinions with each other and provide reviews of products and stores. Through social media, consumers can effectively share their personal experiences of products or brands; thus, social media can significantly affect product sales and the brand image of enterprises directly or indirectly (Yang et al., 2014). Barnes (2014) proposed that social commerce is a branch of e-commerce that supports community interactions and provides online purchasing, product sales, and services through social media. Liang \& Turban (2011) proposed social commerce as the use of social media technology and frameworks to support online communications and help users access products and services. Hence, social commerce includes online business transactions which involves social networking activities and social network sites (Siau \& Erickson, 2011).

Baethge et al., (2016) delineated that social commerce is considered as a relatively new platform which provide consumers to not only purchase products online but also share personal experience, comments and information about products. Social commerce can be categorized into two applications (Liang \& Turban, 2011; Tajvidi et al., 2020). One type is that consumers directly purchase goods or services through platforms. The other type is that enterprises mainly take marketing and advertising ways to attract consumers. That is, social commerce is integrated functions of electronic commerce with social networking applications including providing shopping reviews, recommending products to friends, and discussing product benefits and weaknesses (Gvili \& Levy, 2021; Nakayama \& Wan, 2019). Hence, this study defines social commerce in accordance with Liang \& Turban (2011), Baethge et al., (2016), and Gvili \& Levy (2021), as a new branch of electronic commerce that involves social media components to provide social interactions and information sharing in order to assist consumers to purchase proper goods and services.

Social commerce is a novel method through which enterprises can engage in business activities. Through synergy and participation, the value chain between all participants is formed (Hajli et al., 2017, Wan \& Chen, 2019). Stephen \& Toubia (2010) proposed that social commerce consists of an online social medium through which people can market and sell products and provide services in online markets and in the community. Zhang et al. (2013) and Yadav et al. (2013) suggested that social commerce involves the use of online media where people can collaborate and participate in activities related to the marketing, sales, management, purchasing, and sharing of products and services in online and offline markets and in the community. The process through which enterprises use social media to affect the marketing and sales of products no longer follows the procedure whereby the seller provides product information to the buyer; now, the procedure entails consumer participation in online communication platforms. These concepts affect consumers' dynamic patterns of purchasing behavior. 
Social commerce influences product sales through the effect of the community. Consumers can score and comment on products, brands, and even stores. The reputations of products and brands created by consumers affect the purchasing behavior of other consumers. Therefore, information shared by consumers considerably affects consumers' behavior. Other studies on social commerce focused on consumers' purchasing intentions and behavior (Hajli et al., 2017; Ho \& Wang, 2015) and the effect of word of mouth (Wang \& Yu, 2017). Research on consumers' information sharing behavior is insufficient. Facing the uncertainty and risk of e-commerce and concerns about product value and quality, consumers attempt to collect adequate useful information to reduce these uncertainties. Therefore, product information and consumer experiences and evaluations are essential factors affecting consumers' purchasing decisions. This study focused on consumers' information sharing behavior and explored the establishment of this behavior in social commerce.

\subsection{Social Exchange Theory}

Homans (1958) proposed the idea of social exchange. The primary principle is that social behavior is a type of exchange process, which includes four relationships-behavioral psychology, economics, propositions about the dynamics of influence, and propositions about the structure of small groups. Homans (1958) considered the primary influencing factor of behavior to be reward. If a reward exceeds the cost of undertaking a behavior and meets a person's predetermined expectations, the person will be willing to pay the cost and undertake the behavior. For example, the emergence of human behavior is a dynamic exchange process and may consist of the exchange of material or nonmaterial objects (e.g., money, appreciation, or psychological satisfaction). Blau (1964) and Emerson (1976) modified and extended Homans' theory; however, they retained the idea that the generation of human behavior is a dynamic exchange and the objects of exchange may be money, objects, or satisfaction. If the cost of a behavior can be exchanged for something with equal or higher value, human behavior will be generated; the same concept applies to the value of a product that a consumer believes is equivalent to or exceeds the amount he or she will pay.

The concept of social exchange can not only explain the communication between individuals but also the long-term relationship between individuals and the structure of large social networks (Blau, 1964; Emerson, 1976). If the interaction process between two parties can meet expectations, they will be willing to maintain an interactive relationship with each other because of the accumulating positive experiences (Blau, 1964). Therefore, the generation of behavior is similar to a product trading process, and the obtained goods must be equal to or more than the amount of payment. The establishment of face-to-face interactions and relationships requires reciprocity, and the value of a reward should be equal or more than the cost. If consumers believe that information can be exchanged for other valuable rewards such as other consumers' affirmation and feedback, their belief creates the necessary conditions for an information exchange environment (Moghavvemi et al., 2017).

This study used social exchange theory as the research framework to explore how enterprises can inspire consumers' information exchange behavior with respect to social commerce. The reward of information sharing in the online environment is not necessarily obtained in time, and the information provider, information acquirer, or all the users of the community may participate in the sharing process. However, the participants usually do not know each other, and the relationship between the participants is not as close as that between friends and relatives (Chen \& Shen, 2015; Kim \& Johnson, 2016). The purpose of this study was to explore the factors that affect the generation of consumers' information exchange behavior.

\subsection{Customer Relationship}

The popularity of the Internet and social media have facilitated consumers' online sharing of various information such as ratings, comments, recommendations, and experiences. Consumers' word of mouth indeed affects other consumers' purchasing intentions and behavior (Wang \& Yu, 2017); thus, the influence of consumers in the social commerce environment is critical. This study used 
communication ecology theory (CET) to determine the relationship of consumers in online-tooffline (O2O) commerce (Forth and Hearn, 2007; Seol, Lee, Yu, \& Zo, 2016). CET describes the dynamic relationship between the social layer (e.g., social interaction activities), the content layer (e.g., products, services, or events), and the technological layer (e.g., SNS platform) and analyzes the effects of using information technology in online and offline social networks (Forth and Hearn, 2007; Seol et al., 2016). Therefore, this study extended and applied CET to determine the consumer relationships in three types of $\mathrm{O} 2 \mathrm{O}$ commerce, namely consumer-community, consumer-product/ brand, and consumer-platform relationships.

\subsubsection{Consumer-Community Relationship}

In the social commerce environment, the people with whom consumers mostly interact are other consumers. Consumers often interact with community members through product reviews, opinion exchanges, or opinion inquiries (Hajli et al., 2017). If consumers are on the same community, their attitudes and behaviors easily affect each other. Consumers are willing to participate in community communication because they feel the similarity, trust, and sense of belonging with other people in the community (Seol et al., 2016). The trust that consumers have for the community positively affects their subsequent purchasing and product evaluation behavior (Hajli et al., 2017; Kim, \& Park, 2013). Once consumers have a sense of belonging to a community, it enhances their willingness to participate in it. The consumer-community relationship influences the consumers' willingness to participate in the community and affects their information sharing behavior (Lin, Featherman, \& Sarker, 2016; Seol et al., 2016).

\subsubsection{Consumer-Product/Brand Relationship}

The feelings and values that products and brands inspire in consumers are essential factors that influence consumer attitudes and behaviors (e.g., repurchasing or recommending behaviors). Consumers' past experiences affect their expectations and preferences for products and brands, influence their willingness to purchase a product again, and even affect their trust in the brand (Kaewkitipong, Chen, \& Ractham, 2016). If consumers had a high level of satisfaction with a product in their past experiences, they tend to be willing to not only purchase it again but also share positive experiences with and recommend it to other consumers (Kaewkitipong, Chen, \& Ractham, 2016). In addition, if a brand can provide sufficient information and is responsive to consumers' questions, it can increase consumers' trust in the brand. Consumers then tend to have a high degree of purchasing intention for a product and evaluate it positively (Seol et al., 2016).

\subsubsection{Consumer-Platform Relationship}

The channel through which consumers communicate in the network environment is called a platform. Consumers' experiences and feelings concerning the use of the platform are other crucial factors affecting a consumer's sharing behavior. Social media (e.g., Facebook, YouTube, and Twitter) have different characteristics. Effectively using various social media and establishing long-term relationships with consumers are essential tasks for enterprises (Phua, Jin, \& Kim, 2017; Smith, Fischer, \& Yongjian, 2012; Seol et al., 2016). If the social business platform provides sufficient information and a user-friendly interface and the enterprise provides timely feedback and assistance in response to consumer difficulties, this can attract consumers to visit frequently, increase the probability of a product purchase, and increase the number of consumers' engaging in online discussions concerning products and sharing experiences (Hadji \& Degoulet, 2016; Schultz et al., 2012; Zhang et al., 2017).

\section{RESEARCH MODEL AND HYPOTHESES DEVELOPMENT}

The research model of this study was established on the basis of social exchange theory (Blau, 1964; Emerson, 1976; Homans, 1958). The establishment of a relationship between people is also a social 


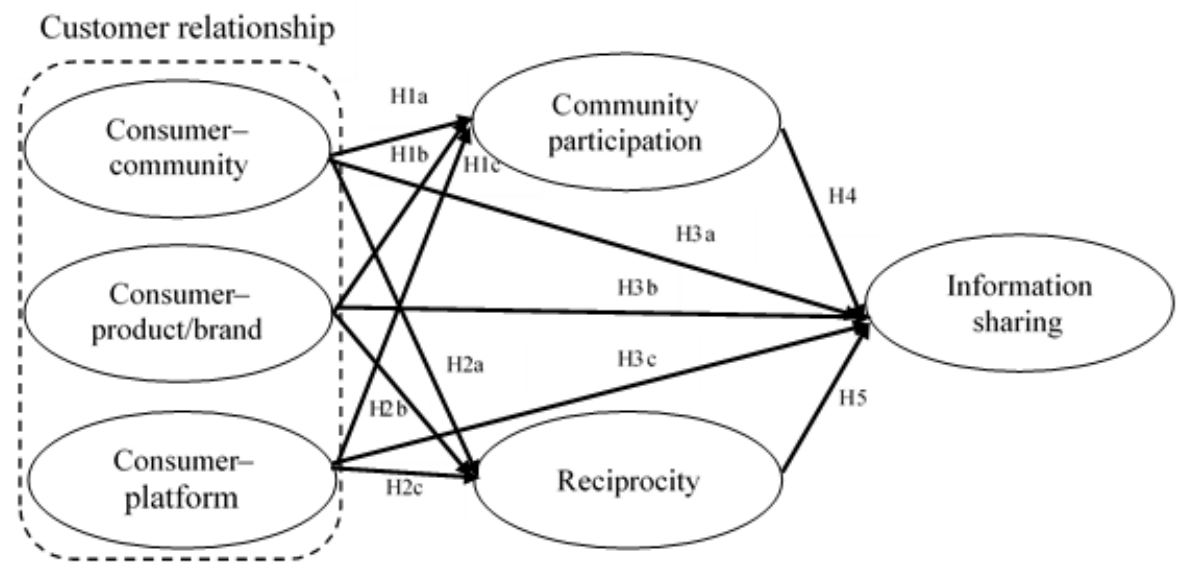

exchange. If the possibility of obtaining a reward is high, the behavior of both parties continues to be generated and an interactive relationship is maintained. The relationship is terminated if one party decides to stop contributing to the relationship (Blau, 1964). Ho \& Wang (2015) proposed that consumer relationships positively affect community participation and community participation positively affects information sharing. Therefore, in social commerce, the community comprised of consumers is influential. Consumers' purchasing behavior is affected by the community; thus, consumers' attitudes with respect to community participation are an essential factor affecting information sharing behavior.

Blau (1964) proposed that reciprocity is a crucial element of social exchange and indicated that social exchange does not specifically regulate how much of a reward either of the two parties should provide. Both sides trust the other party to provide a reward. Usually, the objective of the personal behavior of social exchange is to obtain the maximum benefit at the minimum cost. After consumers share personal experience or information, they may obtain reciprocity (Falk \& Fischbacher, 2006); thus, reciprocity in social commerce positively affects information sharing (Pai \& Tsai, 2016). This study considered reciprocity to be a vital factor. Consumers' purchasing intentions and behavior are affected by past experiences and product review information. Therefore, if enterprises wish to improve their visibility in the product market and increase consumers' purchasing intentions, enterprises should encourage consumers to share their information and opinions. Therefore, the research model of this study was based on the aforementioned ideas (Figure 1).

Consumers' participation in the community includes behaviors such as topic discussions, event participation, and idea exchange (Chen et al., 2015; Hajli et al., 2015; Zhang, Lu, Gupta, \& Zhao, 2014). The interactions between community members provide useful information and emotional support that build long-term friendships (Chen et al., 2015; Tsai \& Pai, 2013). According to Forman, Ghose, \& Wiesenfeld (2008), in the online community, lead users often proactively participate in discussions, share their opinions, and exchange use experiences and thoughts with other consumers. If consumers can find a sense of belonging and a position in the community, they then endeavor to manage their roles and image, actively participate in the community, and continue to interact with members of the community for a long time (Ho \& Wang, 2015). More interactions between consumers and the community lead to a stronger relationship between a consumer and the community and entails information support, emotional support, a sense of belonging, role positioning, and image creation, all of which positively influence consumers to maintain their community participation. Thus, it is hypothesized as follows: 
H1a: The consumer-community relationship positively affects community participation.

Consumers' favorable impressions and thoughts concerning the use experience of a product affect consumers' attitudes towards the brand. Consumers participate in community discussions about the brand and exchange their thoughts and experiences about the brand with other consumers (Brakus et al., 2009). If consumers have a high degree of satisfaction and loyalty to the brand or a positive impression of the brand (e.g., service quality and service focused on the consumer experience), consumers continue purchasing the brand's products, establish positive word of mouth, and recommend products in the community. This behavior affects other consumers' purchasing intentions (Gecti \& Zengin, 2013; Erdoğmuş \& Tatar, 2015; Fu et al., 2015). The results of consumers' product or brand experiences influence consumers' intentions and behavior (Brakus et al., 2009). For example, brand marketing personnel and consumers maintain a relationship and constantly exchange opinions. The relationship provides consumers with useful information and increases consumers' brand satisfaction. Therefore, consumers are willing to interact with other consumers in the community (Yuan et al., 2016; Zhang et al., 2016). Hence, we propose the following hypothesis:

H1b: The consumer-product/brand relationship positively affects community participation.

Consumers can share information and knowledge on social platforms and also establish cooperative relationships with other consumers; these activities become part of consumers' routines (Zhang et al., 2017). Therefore, consumers' willingness to use platforms affects the consumers' use behavior of the platform. If consumers believe that the functions and content provided by the platform meet their expectations, then consumers use the platform frequently and communicate with other consumers through the platform, actively participating in community activities (Seol et al., 2016). The community platform provides the environment for consumers to share their consumption experiences and subjective opinions. If the platform is characterized by the presence of sufficient consumption information that is correct and integrated and the platform functions are stable, instant, and userfriendly, consumers' willingness to participate in social commerce is increased (Ho \& Wang, 2015; Kaewkitipong et al., 2016). If consumers believe that participating in the platform is helpful for obtaining useful information or social benefits, their willingness to participate in social commerce platforms is improved (Ho \& Wang, 2015). The hypothesis is built as follows:

H1c: The consumer-platform relationship positively affects community participation.

Interactions between consumers and the community provide consumers with emotional support and useful information, which affect the consumers' helping behavior where the consumers try to return the support to the community (Chan \& Li, 2010; Pai \& Tsai, 2016; Zhu et al., 2016). If the coherence of the social network is strong and the members are close, more helping behaviors are generated to help other members; for example, in a highly interactive community, members are willing to share their knowledge and help solve the difficulties of other members (Wasko \& Faraj, 2005). If consumers are essential to the community, the importance they feel about themselves generates coherence and a sense of belonging to the community, which encourages consumers to engage in reciprocal behaviors (Chan \& $\mathrm{Li}, 2010$ ). If consumers feel support from other community members, these feelings increase the consumers' participation intention in the community; thus, the consumers are willing to interact with community members (Liang, Ho, Li, \& Turban, 2011). Social support affects consumers' attitudes towards the community. When consumers believe that interactions with community members are not unilateral, reciprocal attitudes and behavior are naturally undertaken (Liang et al., 2011; Yuan et al., 2016). Thus: 
H2a: The consumer-community relationship positively affects reciprocity.

Talja (2002) proposed that reciprocity is an essential factor affecting consumer behavior. If consumers believe that a brand's products are worth more than they cost or positively evaluate the brand and its products, consumers tend to have a strong intention to purchase products again and recommend the brand to relatives and friends (Brakus et al., 2009; Fu et al., 2015; Yang \& Fryxell, 2009). If consumers are satisfied with the service and values provided by the product and brand, consumers perceive their substantial interests and consider themselves to be in a mutually beneficial relationship (Chaudhuri \& Holbrook, 2001). In addition, if product suppliers or brand marketing personnel often explore consumers' needs through community platforms, frequently update activity information, actively interact with consumers, and provide services that satisfy consumers, consumers tend to feel emotional support and actively reciprocate in the community (Chan \& Li, 2010; Gecti $\&$ Zengin, 2013). Hence, we propose the following hypothesis:

\section{H2b: The consumer-product/brand relationship positively affects reciprocity.}

The social commerce platform is a channel in which consumers can search for and share product information or purchase products. If the platform meets consumers' needs and has a simple and user-friendly interface that engenders consumers' positive attitudes towards the platform, consumers continue to use it. In addition to using the platform, they also tend to be willing to reciprocate with other consumers (Liang et al., 2011; Hadji \& Degoulet, 2016). Moreover, the usability, entertainment, and community influence of the platforms also affect consumer satisfaction and their attitude of reciprocity towards the platform (Lin et al., 2016; Kaewkitipong et al., 2016; Seol et al., 2016). In addition, some platforms create consumer award systems. If consumers believe that using the platform can benefit them, including through the acquisition of useful information, exchanging opinions, or simply pleasure, the consumers' tend to believe that the platform provides a fair and mutually reciprocal system (Seol et al., 2016). The hypothesis is built as follows:

$\mathrm{H} 2 \mathrm{c}$ : The consumer-platform relationship positively affects reciprocity.

An information encounter refers to the situation where consumers obtain useful information that transcends their personal expectations and this information is obtained from other consumers' information sharing (Talja, 2002). Information sharing and access can be regarded as a type of cooperative behavior in which obtained information is shared with other consumers and allows the information to generate different values for different consumers. Information sharing can promote social communication, and social communication is accompanied by information sharing (Talja, 2002). Consumers use the community to share information with other members. If the members consider the information to be useful and correct, the information sharing behavior enhances the trust among community members (Hsu \& Chang, 2014). In addition, the frequency of communication among community members also positively affects knowledge sharing behaviors (Chang \& Chuang, 2011; Chiu et al., 2006; Kwahk \& Park, 2016) and information sharing behaviors (Shang, Wu, \& $\mathrm{Li}$, 2017). Therefore, the closeness between community members affects community members' decisions to share personal experiences and useful information (Chung, Nam \& Koo, 2016). Thus, it is hypothesized as follows:

H3a: The consumer-community relationship positively affects information sharing behavior.

Brand image influences consumers' purchasing intentions. If a brand's products meet consumers' needs and generate high levels of consumer satisfaction, consumers tend to positively evaluate the 
brand (Cheung, Lee, \& Lee, 2013). Effectively communicating with consumers is an essential process. If a company can provide consumers with the information they need, respond to consumer questions, frequently communicate with consumers, and increase emotional support, consumers tend to be willing to recommend the brand to other consumers (Zhu et al., 2016). Specifically, after consumers obtain a satisfactory response from the community, the consumers tend to empathically reciprocate with other consumers on the platform (Cheung et al., 2013; Hashim \& Tan, 2015). If a brand is willing to communicate with consumers frequently to assist consumers with solving problems related to products, this can enhance consumers' intention to continue sharing information (Cheung, Lee, \& Lee, 2013; Hashim \& Tan, 2015). The hypothesis is built as follows:

H3b: The consumer-product/brand relationship positively affects information sharing behavior.

Consumers' information sharing on the Internet is mediated by a platform. The functions and features of the platform affect consumers' willingness to use it. When consumers are willing to continue to use a platform, the platform's value and usefulness are confirmed (Kaewkitipong et al., 2016). Consumers use community platforms to search for information related to products (including reviews, word of mouth, and user-generated content), to solve the problems they have with products, and to improve the quality of their purchasing decisions. Therefore, the platform provides consumers with a channel for sharing and accessing information. If consumers are highly satisfied with the platform, it affects consumers' information sharing behavior (Yuan et al., 2016). The social platform provides the functions required by consumers (including community communication and entertainment functions) and gives consumers positive experiences. When consumers are satisfied with the platform, consumers tend to spontaneously share personal experiences and reciprocate (Lin et al., 2016; Seol et al., 2016). Thus:

H3c: The consumer-platform relationship positively affects information sharing behavior.

Rioux (2005) proposed that information acquisition and information sharing are interrelated. Received information does not necessarily meet the receivers' needs. Therefore, if the information receivers actively provide the obtained information and assist others in making decisions or provide relevant advice, these measures give the information different values. Therefore, information sharing can be regarded as a cooperative behavior (Yu, Lan \& Zhao, 2018; Talja, 2002). Information sharing involves information receivers and information sharers. If both parties trust each other and have a stable relationship, information sharing behavior is generated naturally (Hansen \& Järvelin, 2005). The higher the level a consumer's community participation is, the greater the sense of belonging in the community she has. Consumers can be willing to communicate, discuss, share information, share experience, and provide word-of-mouth recommendations in the community (Chang \& Chuang, 2011; Royo-Vela \& Casamassima, 2011). Community participation improves the close relationships between consumers because they trust and understand each other; this encourages consumers to share information with each other (Algesheimer, Dholakia, \& Herrmann, 2005; Chung et al., 2016; Kwahk $\&$ Park, 2016). Thus, it is hypothesized as follows:

H4: Community participation has a significantly positive effect on information sharing behavior.

Reciprocity affects consumers' intentions and behaviors. Consumers self-explore and reflect on themselves and assess whether their behavior is in line with norms and pay attention to determine if the interest exchange between them and others is fair (Pai \& Tsai, 2016). Grant and Preston (2018) proposed that information sharing occurs in the cooperative behavior of social networks. Participants gain benefits through information sharing to achieve common goals. The interaction and trust 
relationship also encourages participants to share information. Information sharing behaviors can be regarded as reciprocal cooperative behavior between the information provider and the receiver. The information provider shares personal experiences and opinions with the information receiver, and thus the shared information has new values (Talja, 2002). Pai and Tsai (2016) suggested that in the social commerce environment, reciprocity positively affects consumers' information sharing behavior. Reciprocity norms positively affect users' knowledge sharing behavior in social media (Kwahk \& Park, 2016). Therefore, according to the viewpoint of reciprocity, after consumers obtain useful information, information sharing behavior is generated on the basis of the obligations of reciprocity (Moghavvemi et al., 2017). Hence, we propose the following hypothesis:

H5: Reciprocity positively affects information sharing behavior.

\section{METHODOLOGY}

\subsection{Measurement Development}

This study collected data by distributing a questionnaire. The content solicited by the questionnaire was divided into two parts. The first part inquired as to the consumers' information sharing behavior on the social commerce platform, and the second part asked for personal information. Experts in three fields were first invited to conduct a semantic and wording review of the narratives of each item, and then the narration was adjusted according to the experts' suggestions to improve the content validity of the questionnaire. A pretest was conducted by distributing the questionnaire online, and some items were deleted according to the reliability and validity of the pretest. Table 1 provides the definitions of constructs used in our research model with referred studies. All scale items were measured on seven-point Likert scales that ranged from strongly disagree (1) to strongly agree (7).

\subsection{Data Collection}

We conducted a survey to collect primary data from active consumers on social commerce platforms in Taiwan. The inclusion criteria were that respondents should have (1) been involved in at least one social commerce platform, and (2) contributed at least one discussion or comment to social commerce platforms. To encourage participation, a lottery draw for twenty NT \$200 (US\$6) convenience store gift certificates was offered. A total of 482 copies were distributed, 244 copies were recovered, and 40 invalid copies were excluded. A total of 204 copies were valid, and the response rate was $42.3 \%$ (Table 2).

\section{DATA ANALYSIS AND RESULTS}

\subsection{Data Analysis Technique}

Structural equation modeling (SEM) is to examine research models and investigate the relations between exogenous and endogenous structures (Choshin \& Ghaffari, 2017). According to Wong (2013) and Hwang and Kim (2018), the partial least squares (PLS) of SEM can be adopted to studies with low sample size requirement and little appropriate theoretical grounding. The PLS also is a flexible method to build complicated research models including reflective and formative indicators (Lowry \& Gaskin, 2014). The PLS does not require normal distribution (Hair, Hult, Ringle, \& Sarstedt, 2016) and can be applied to examine variables with fewer items (Kovacevic, Abdi, \& Beaton, 2013). Yi and Gong (2009) addressed that the PLS analysis is suitable used in explorative research in marketing field. Meanwhile, the variables in this study were unobservable variables. Therefore, this study used the PLS for analysis. Through indicator variables, the PLS was used to incorporate indirectly measured unobservable variables into this study and to calculate the measurement error of observed 
Table 1. Summarized definition of construct

\begin{tabular}{|l|l|l|}
\hline \multicolumn{1}{|c|}{ Construct } & \multicolumn{1}{|c|}{ Definition } & \multicolumn{1}{|c|}{ Reference } \\
\hline Consumer-community (CC) & $\begin{array}{l}\text { The extent to which consumers perceive that they } \\
\text { intend to interact with community members }\end{array}$ & $\begin{array}{l}\text { Ho \& Wang (2015) } \\
\text { Seol et al. (2016) }\end{array}$ \\
\hline $\begin{array}{l}\text { Consumer-product/brand } \\
\text { (CPB) }\end{array}$ & $\begin{array}{l}\text { The extent to which consumers perceive that they } \\
\text { intend to understand the products/brands }\end{array}$ & $\begin{array}{l}\text { Ho \& Wang (2015) } \\
\text { Seol et al. (2016) }\end{array}$ \\
\hline Consumer-platform (CP) & $\begin{array}{l}\text { The extent to which consumers perceive that they } \\
\text { intend to use the O2O platforms }\end{array}$ & Seol et al. (2016) \\
\hline $\begin{array}{l}\text { Community participation } \\
\text { (CPA) }\end{array}$ & $\begin{array}{l}\text { The extent to which consumers perceive that they } \\
\text { intend to take part in community activities }\end{array}$ & Khan (2017) \\
\hline Reciprocity (REC) & $\begin{array}{l}\text { The extent to which consumers perceive that they } \\
\text { intend to support members in return for community } \\
\text { members' help to them }\end{array}$ & Pai \& Tsai (2016) \\
\hline Information sharing (IS) & $\begin{array}{l}\text { The extent to which consumers perceive that they } \\
\text { intend to share their information with community } \\
\text { members }\end{array}$ & $\begin{array}{l}\text { Rioux (2005) } \\
\text { Grant \& Preston (2019). }\end{array}$ \\
\hline
\end{tabular}

variables (Hair, Black, Babin \& Anderson, 2018). The PLS was used to verify models and develop a theory without generating unreasonable estimates or unrecognized models. Consequently, this study adopted bootstrapping for small samples to verify reflective and formative indicators (Hair, Sarstedt, Hopkins, \& Kuppelwieser, 2014; Hair \& Hult, 2016).

\subsection{Measurement Model}

The reliability and validity of the measurement model were first analyzed (Table 3). Individual item reliability refers to the degree to which each variable could be explained by a latent variable. According to factor loading $(>0.5)$, as suggested by Hair et al. (1992), all the factor loading in this study was higher than 0.8. Furthermore, Cronbach's Alpha was used to assess the constructs' reliability scores and all the scores were above a 0.80 threshold, which is higher than the 0.7 threshold that determines reliable constructs as suggested by Cronbach (1951). Composite reliability refers to the consistency of the latent variables inside the construct. If the value is high, the measurement variable is highly correlated. Hair et al. (2018) suggested that the CR value should be higher than 0.7. All the CR values in this study were higher than 0.8 , indicating favorable internal consistency of the constructs. Therefore, the questions in this study exhibited fair reliability.

Average variance extracted (AVE) was primarily used to determine whether each item could effectively measure the latent variables and thus serve as an indicator for measuring the convergence validity. Fornell \& Larcker (1981) suggested 0.5 as the threshold for determining whether convergent validity was achieved. The AVE of each construct in this study was higher than 0.5 , indicating that the questionnaire in this study exhibited fine convergent validity. In addition, Table 4 indicates that the correlation coefficients between various constructs were lower than 0.85 (Kline, 2016) and the square root values of the AVE of each construct were greater than the correlation coefficients between the constructs (Fornell \& Larcker, 1981). The factor loading of the variables and explained constructs was higher than that of the variables and nonexplained constructs (Table 5). Therefore, the items in the questionnaire exhibited favorable discriminant validity.

\subsection{Structural Model}

The results of the study are presented in Figure 2 and Table 6 . The consumer-community relationship had a significantly positive effect on community participation behavior $(\beta=.2920$, $p<.01)$; thus, hypothesis H1a was supported. The consumer-product/brand relationship did not significantly affect 
Table 2. Descriptive Information about Respondents

\begin{tabular}{|c|c|c|c|}
\hline Measure & Items & Numbers & Percentages \\
\hline \multirow{2}{*}{ Gender } & Female & 127 & $62.3 \%$ \\
\hline & Male & 77 & $37.7 \%$ \\
\hline \multirow{6}{*}{ Age } & $<18$ & 3 & $1.5 \%$ \\
\hline & $18-24$ & 178 & $87.3 \%$ \\
\hline & $25-30$ & 14 & $6.9 \%$ \\
\hline & $31-35$ & 5 & $2.5 \%$ \\
\hline & $36-40$ & 1 & $0.5 \%$ \\
\hline & $>41$ & 3 & $1.5 \%$ \\
\hline \multirow{3}{*}{ Education } & Secondary Education & 2 & $1.0 \%$ \\
\hline & University (Bachelor) & 162 & $79.4 \%$ \\
\hline & University (Master) & 40 & $19.6 \%$ \\
\hline \multirow{6}{*}{$\begin{array}{l}\text { Which platforms do you } \\
\text { participate in? (You can have } \\
\text { multiple answers) }\end{array}$} & $\begin{array}{l}\text { Social network sites (Facebook, YouTube, } \\
\text { Pinterest, Instagram, Snapchat, Twitter, } \\
\text { LinkedIn etc.) }\end{array}$ & 190 & $40.1 \%$ \\
\hline & $\begin{array}{c}\text { Shopping websites } \\
\text { (Yahoo, Taobao, Shopee, Amazon, Lyst, } \\
\text { Soldsie etc.) }\end{array}$ & 56 & $11.8 \%$ \\
\hline & $\begin{array}{l}\text { Online review websites } \\
\text { (TripAdvisor, EZTABLE, Yelp, Mobile01, } \\
\text { UrCosme etc.) }\end{array}$ & 42 & $8.9 \%$ \\
\hline & $\begin{array}{c}\text { Group-buying websites (Groupon, GOMAJI, } \\
\text { GoodLife etc.) }\end{array}$ & 174 & $36.7 \%$ \\
\hline & $\begin{array}{l}\text { Crowdfunding platforms } \\
\text { (Kickstarter, flyingV etc.) }\end{array}$ & 9 & $1.9 \%$ \\
\hline & $\begin{array}{c}\text { Social commerce platforms } \\
\text { (OpenSky, the fancy, Rocomi etc.) }\end{array}$ & 3 & $0.6 \%$ \\
\hline \multirow{5}{*}{ Frequency } & Never & 0 & $0.0 \%$ \\
\hline & Once a day & 73 & $35.8 \%$ \\
\hline & Several times a day & 55 & $27.0 \%$ \\
\hline & $>$ Once a week & 30 & $14.7 \%$ \\
\hline & $>$ Once a month & 46 & $22.5 \%$ \\
\hline
\end{tabular}

community participation behavior $(\beta=-.0366, \mathrm{p}>.05)$; thus, hypothesis H1b was not supported. The consumer-platform relationship had a significantly positive effect on community participation behavior $(\beta=.4548, \mathrm{p}<.001)$; thus, hypothesis H1c was supported. The consumer-community relationship had a significantly positive effect on reciprocity $(\beta=.2119, \mathrm{p}<.05)$; thus, hypothesis $\mathrm{H} 2 \mathrm{a}$ was supported. The consumer-product/brand relationship had a significantly positive effect on reciprocity $(\beta=.3557, \mathrm{p}<.001)$; thus, hypothesis $\mathrm{H} 2 \mathrm{~b}$ was supported. The consumer-platform relationship had a significantly positive effect on reciprocity $(\beta=.3124, \mathrm{p}<.001)$; thus, hypothesis $\mathrm{H} 2 \mathrm{c}$ was supported. The consumer-community relationship did not significantly affect information sharing behavior $(\beta=-.0671, \mathrm{p}>.05)$; thus, hypothesis H3a was not supported. The consumerproduct/brand relationship had a significantly positive effect on information sharing behavior $(\beta=$ 
Table 3. Measurement Model Constructs

\begin{tabular}{|c|c|c|c|c|c|c|}
\hline \multicolumn{2}{|c|}{ Constructs } & Items & FL & CR & AVE & $\begin{array}{c}\text { Cronbach's } \\
\text { Alpha }\end{array}$ \\
\hline \multirow{10}{*}{$\begin{array}{l}\text { Customer } \\
\text { relationship }\end{array}$} & \multirow{3}{*}{$\begin{array}{l}\text { Consumer- } \\
\text { community }\end{array}$} & $\mathrm{CC} 1$ & 0.921 & \multirow{3}{*}{0.957} & \multirow{3}{*}{0.881} & \multirow{3}{*}{0.932} \\
\hline & & $\mathrm{CC} 2$ & 0.953 & & & \\
\hline & & $\mathrm{CC} 3$ & 0.942 & & & \\
\hline & \multirow{3}{*}{$\begin{array}{l}\text { Consumer- } \\
\text { product/brand }\end{array}$} & CPB1 & 0.868 & \multirow{3}{*}{0.910} & \multirow{3}{*}{0.772} & \multirow{3}{*}{0.852} \\
\hline & & CPB2 & 0.862 & & & \\
\hline & & CPB3 & 0.904 & & & \\
\hline & \multirow{4}{*}{$\begin{array}{l}\text { Consumer- } \\
\text { platform }\end{array}$} & $\mathrm{CP} 1$ & 0.888 & \multirow{4}{*}{0.915} & \multirow{4}{*}{0.729} & \multirow{4}{*}{0.876} \\
\hline & & $\mathrm{CP} 2$ & 0.801 & & & \\
\hline & & $\mathrm{CP} 3$ & 0.888 & & & \\
\hline & & $\mathrm{CP} 4$ & 0.835 & & & \\
\hline \multirow{3}{*}{\multicolumn{2}{|c|}{ Community participation }} & CPA1 & 0.865 & \multirow{3}{*}{0.890} & \multirow{3}{*}{0.730} & \multirow{3}{*}{0.876} \\
\hline & & CPA2 & 0.835 & & & \\
\hline & & CPA3 & 0.863 & & & \\
\hline \multirow{6}{*}{\multicolumn{2}{|c|}{ Reciprocity }} & REC1 & 0.849 & \multirow{6}{*}{0.948} & \multirow{6}{*}{0.752} & \multirow{6}{*}{0.934} \\
\hline & & REC2 & 0.909 & & & \\
\hline & & REC3 & 0.884 & & & \\
\hline & & REC4 & 0.858 & & & \\
\hline & & REC5 & 0.828 & & & \\
\hline & & REC6 & 0.871 & & & \\
\hline \multirow{3}{*}{\multicolumn{2}{|c|}{ Information sharing }} & IS1 & 0.926 & \multirow{3}{*}{0.938} & \multirow{3}{*}{0.834} & \multirow{3}{*}{0.900} \\
\hline & & IS2 & 0.940 & & & \\
\hline & & IS3 & 0.873 & & & \\
\hline
\end{tabular}

$.2714, \mathrm{p}<.001$ ); thus, hypothesis H3b was supported. The consumer-platform relationship did not significantly affect the information sharing behavior $(\beta=.1455, \mathrm{p}>.05)$. Community participation significantly and positively affected information sharing $(\beta=.3124, \mathrm{p}<.001)$; thus, hypothesis $\mathrm{H} 4$ was supported. Reciprocity significantly and positively affected information sharing $(\beta=.2520, \mathrm{p}<$ $.01)$; thus, hypothesis H5 was supported.

\subsection{Mediation Test}

The consumer-community and consumer-platform relationships did not directly affect information sharing; however, they positively affected community participation and reciprocity. Moreover, both community participation and reciprocity positively affected information sharing behavior. Therefore, this study analyzed the mediation effect of the two latent variables (community participation and reciprocity) on the effects of the consumer-community and consumer-platform relationships on information sharing. Specifically, this study investigated whether the consumer-community and consumer-platform relationships indirectly affected information sharing behavior. As depicted in Figs. 3-6, each variable exhibited a significantly positive effect on the other. This study determined the mediation effect by calculating the path coefficients of indirect and direct effects. In the past, Sobel verification was used to verify mediation effects. However, Hair et al. (2014) contended that 
Figure 2. Results of PLS analysis

Customer relationship

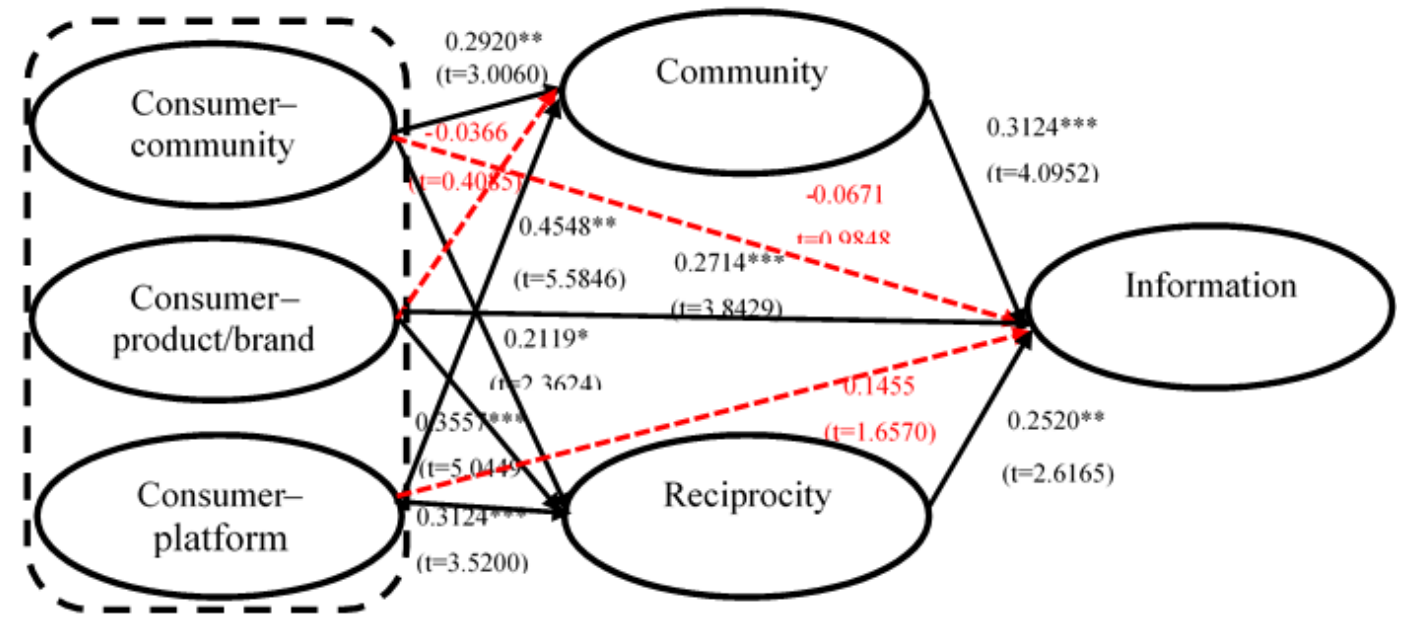

Sobel verification was inadequate for statistical appraisal of small samples. The PLS method uses bootstrapping and thus its verification power is higher than that of Sobel verification; therefore, this study applied PLS verification to the mediation effect using Variance Accounted For (VAF). VAF refers to the percentage of indirect effect of the total effect. If VAF $<20 \%$, no mediation effect exists; if $20 \% £ \mathrm{VAF} £ 80 \%$, a partial mediation effect exists; and if VAF $>80 \%$, a full mediation effect exists (Hair \& Hult, 2016).

As presented in Table 7, the VAF value of the effects of community participation on the consumer-community relationship and information sharing behavior was $43.48 \%$, indicating a partial mediation effect. The VAF value of the effects of community participation on the consumercommunity relationship and information sharing behavior was $34.79 \%$, indicating a partial mediation effect. If consumers were not only involved in the use of social platforms to search for information but also became part of the community on the community platform and actively participated in various

Table 4. Construct correlations

\begin{tabular}{|c|c|c|c|c|c|c|}
\hline Construct & $\begin{array}{c}\text { Consumer } \\
\text {-Community }\end{array}$ & $\begin{array}{c}\text { Consumer } \\
\text {-Product/Brand }\end{array}$ & $\begin{array}{c}\text { Consumer } \\
\text {-Platform }\end{array}$ & $\begin{array}{c}\text { Community } \\
\text { Participation }\end{array}$ & Reciprocity & $\begin{array}{c}\text { Information } \\
\text { Sharing }\end{array}$ \\
\hline $\begin{array}{c}\text { Consumer } \\
\text {-Community }\end{array}$ & $\mathbf{0 . 9 3 9}$ & & & & & \\
\hline $\begin{array}{c}\text { Consumer } \\
\text {-Product/Brand }\end{array}$ & 0.689 & $\mathbf{0 . 8 7 8}$ & & & & \\
\hline $\begin{array}{c}\text { Consumer } \\
\text {-Platform }\end{array}$ & 0.726 & 0.648 & $\mathbf{0 . 8 5 4}$ & & & \\
\hline $\begin{array}{c}\text { Community } \\
\text { Participation }\end{array}$ & 0.597 & 0.459 & 0.643 & $\mathbf{0 . 8 5 4}$ & & \\
\hline Reciprocity & 0.682 & 0.703 & 0.694 & 0.521 & $\mathbf{0 . 8 6 7}$ & \\
\hline $\begin{array}{c}\text { Information } \\
\text { Sharing }\end{array}$ & 0.584 & 0.640 & 0.648 & 0.622 & 0.661 & $\mathbf{0 . 9 1 3}$ \\
\hline
\end{tabular}


Table 5. Cross loadings

\begin{tabular}{|c|c|c|c|c|c|c|}
\hline & $\begin{array}{l}\text { Consumer } \\
\text {-community }\end{array}$ & $\begin{array}{c}\text { Consumer } \\
\text {-product/brand }\end{array}$ & $\begin{array}{l}\text { Consumer } \\
\text {-platform }\end{array}$ & $\begin{array}{c}\text { Community } \\
\text { participation }\end{array}$ & Reciprocity & $\begin{array}{c}\text { Information } \\
\text { sharing }\end{array}$ \\
\hline $\mathrm{CC} 1$ & 0.921 & 0.669 & 0.664 & 0.563 & 0.637 & 0.523 \\
\hline $\mathrm{CC} 2$ & 0.953 & 0.661 & 0.711 & 0.567 & 0.649 & 0.564 \\
\hline $\mathrm{CC} 3$ & 0.942 & 0.610 & 0.668 & 0.550 & 0.634 & 0.557 \\
\hline CPB1 & 0.630 & 0.868 & 0.580 & 0.409 & 0.645 & 0.558 \\
\hline $\mathrm{CPB} 2$ & 0.544 & 0.862 & 0.537 & 0.392 & 0.543 & 0.495 \\
\hline CPB3 & 0.635 & 0.904 & 0.587 & 0.408 & 0.654 & 0.624 \\
\hline $\mathrm{CP} 1$ & 0.657 & 0.570 & 0.888 & 0.602 & 0.590 & 0.545 \\
\hline $\mathrm{CP} 2$ & 0.539 & 0.416 & 0.801 & 0.487 & 0.497 & 0.434 \\
\hline $\mathrm{CP} 3$ & 0.650 & 0.592 & 0.888 & 0.576 & 0.651 & 0.611 \\
\hline $\mathrm{CP} 4$ & 0.622 & 0.612 & 0.835 & 0.524 & 0.618 & 0.605 \\
\hline CPA1 & 0.602 & 0.520 & 0.647 & 0.865 & 0.592 & 0.607 \\
\hline CPA2 & 0.376 & 0.243 & 0.411 & 0.835 & 0.264 & 0.428 \\
\hline CPA3 & 0.510 & 0.362 & 0.546 & 0.863 & 0.418 & 0.527 \\
\hline REC1 & 0.531 & 0.576 & 0.566 & 0.388 & 0.849 & 0.465 \\
\hline REC2 & 0.626 & 0.620 & 0.601 & 0.437 & 0.909 & 0.583 \\
\hline REC3 & 0.649 & 0.605 & 0.615 & 0.413 & 0.884 & 0.554 \\
\hline REC4 & 0.613 & 0.579 & 0.554 & 0.437 & 0.858 & 0.508 \\
\hline REC5 & 0.524 & 0.599 & 0.629 & 0.541 & 0.828 & 0.628 \\
\hline REC6 & 0.599 & 0.664 & 0.634 & 0.481 & 0.871 & 0.670 \\
\hline IS1 & 0.488 & 0.556 & 0.547 & 0.535 & 0.563 & 0.926 \\
\hline IS2 & 0.525 & 0.617 & 0.598 & 0.542 & 0.624 & 0.940 \\
\hline IS3 & 0.581 & 0.577 & 0.625 & 0.621 & 0.618 & 0.873 \\
\hline
\end{tabular}

community communications and activities, this participation would increase the opportunity for consumers to actively share personal information. The VAF value of the effect of reciprocity on the consumer-community relationship and information sharing behavior was $57.16 \%$, demonstrating a partial mediation effect. The VAF value of the effect of reciprocity on the consumer-platform relationship and information sharing behavior was $76.88 \%$, also indicating a partial mediation effect. For consumers who had received help from other community members or have used the services provided by the social platform, reciprocity motivated them to help share useful information with other community members.

\subsection{Discussion}

All hypotheses were supported except for hypotheses H1b, H3a, and H3c. Community participation and reciprocity exhibited partial mediation effects. The reasons $\mathrm{H} 1 \mathrm{~b}$ was not supported were as follows. First, the consumer-product/brand relationship emphasized consumers' past experience with products and brands; these past experiences primarily affected consumers' perceptions and attitudes towards the products and brands and easily induced information sharing behavior. The consumer-product/brand relationship did not affect the intentions and behaviors of consumers with respect to participating in the community. Second, if consumers had a satisfactory relationship with products and brands, 
Table 6. Structural testing results

\begin{tabular}{|c|c|c|}
\hline Hypothesized path & Standardized path coefficients & Result \\
\hline $\begin{array}{l}\text { H1a: Consumer-community }{ }^{\circledR C O m m u n i t y ~} \\
\text { participation }\end{array}$ & $0.2920(3.0060)$ & Supported \\
\hline $\begin{array}{l}\text { H1b: Consumer- product/brand } ® C o m m u n i t y ~ \\
\text { participation }\end{array}$ & $-0.0366(0.4085)$ & Not supported \\
\hline H1c: Consumer-platform ®Community participation & $0.4548(5.5846)$ & Supported \\
\hline H2a: Consumer-community ${ }^{\circledR}$ Reciprocity & $0.2119(2.3624)$ & Supported \\
\hline $\mathrm{H} 2 \mathrm{~b}$ : Consumer- product/brand ®Reciprocity & $0.3557(5.0449)$ & Supported \\
\hline $\begin{array}{l}\text { H2c: Consumer-platform }{ }^{\circledR} \\
\text { Reciprocity }\end{array}$ & $0.3124(3.5200)$ & Supported \\
\hline H3a: Consumer-community ®Information sharing & $-0.0671(0.9848)$ & Not supported \\
\hline H3b: Consumer-product/brand ®Information sharing & $0.2714(3.8429)$ & Supported \\
\hline $\begin{array}{l}\text { H3c: Consumer-platform }{ }^{\circledR} \\
\text { Information sharing }\end{array}$ & $0.1455(1.6570)$ & Not supported \\
\hline H4: Community participation ®Information sharing & $0.3124(4.0952)$ & Supported \\
\hline H5: Reciprocity ®Information sharing & $0.2520(2.6165)$ & Supported \\
\hline
\end{tabular}

Figure 3. Mediation test: consumer-community, community participation and information sharing

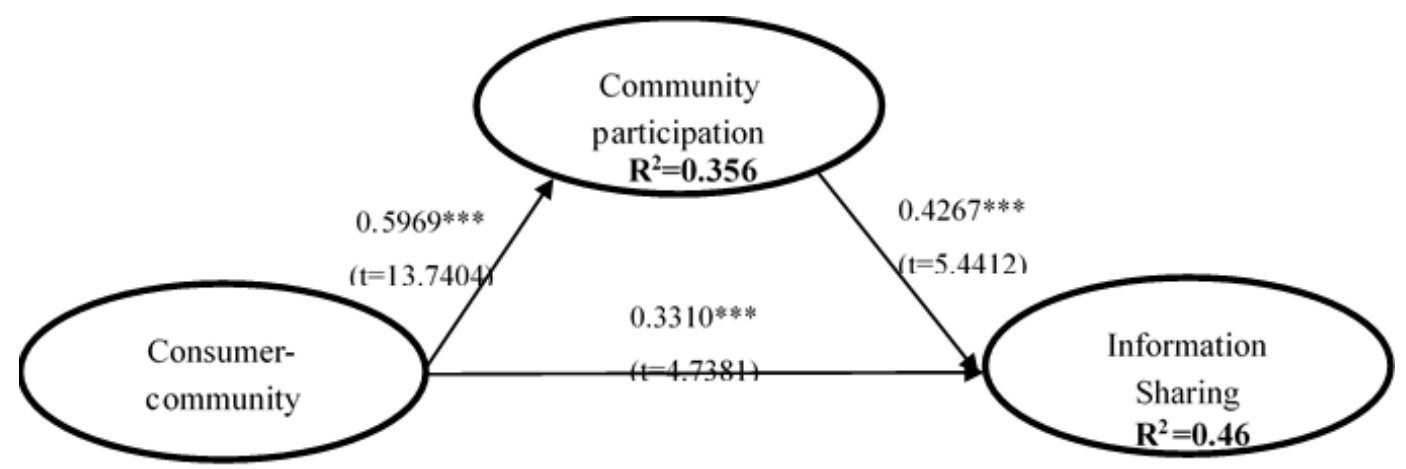

Figure 4. Mediation test: consumer-platform, community participation and information sharing

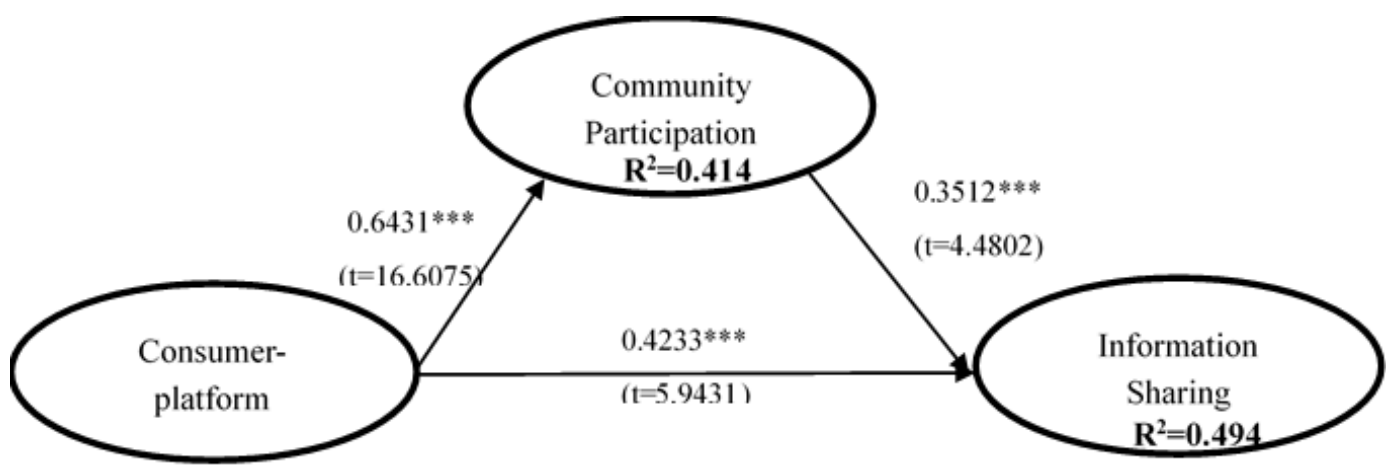


Figure 5. Mediation test: consumer-community, reciprocity and information sharing

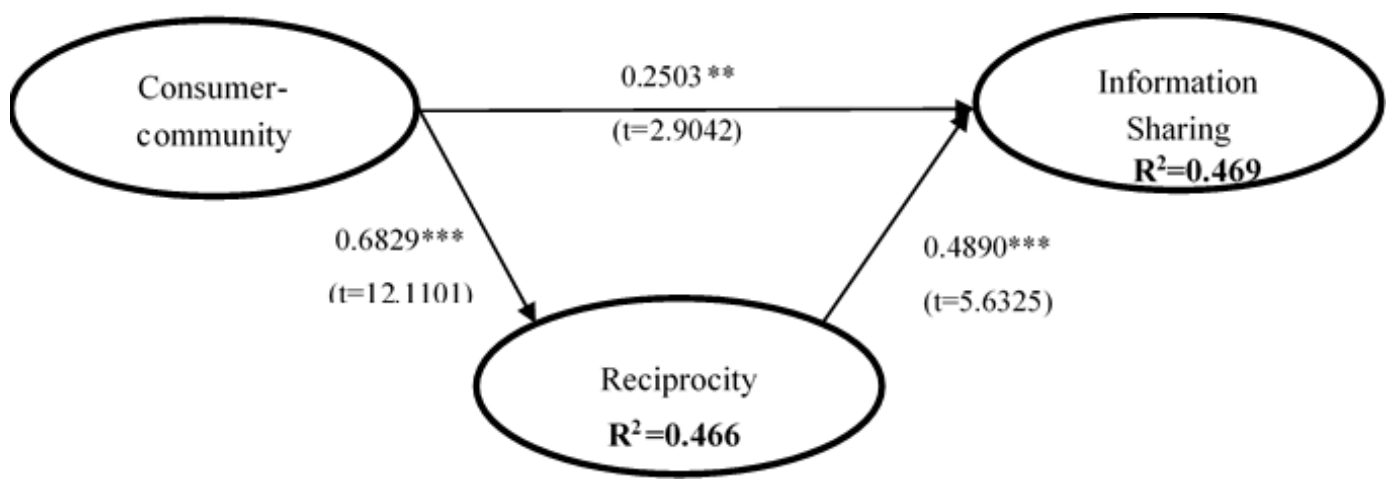

Figure 6. Mediation test: consumer-platform, reciprocity and information sharing

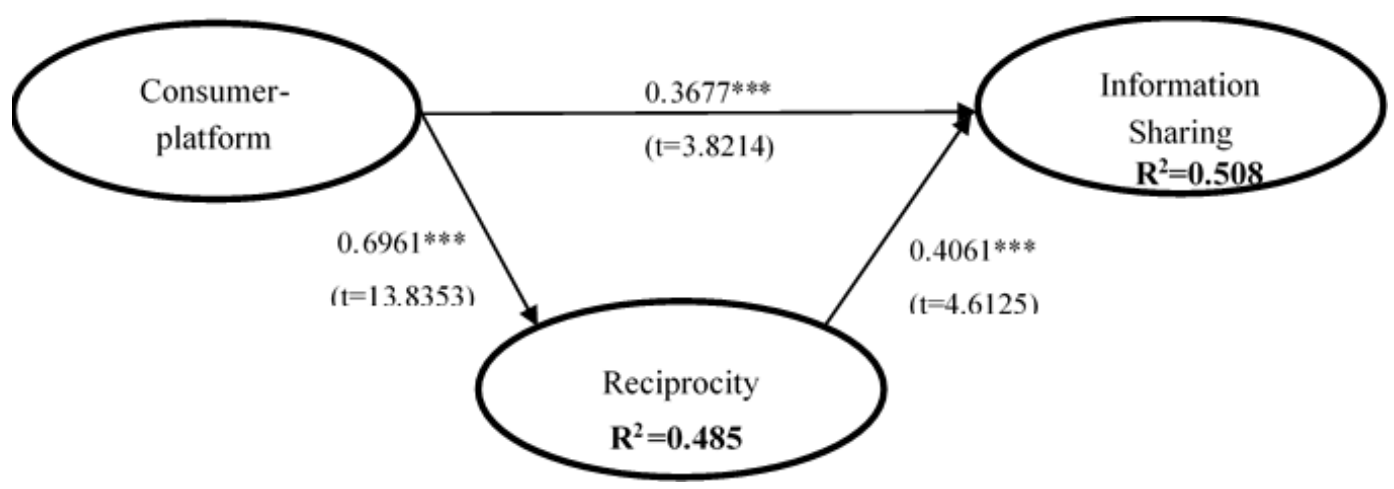

Table 7. The mediating role of community participation and reciprocity

\begin{tabular}{|c|c|c|c|c|}
\hline Path & Indirect effect & Indirect effect & VAF & $\begin{array}{c}\text { Mediation type } \\
\text { observed }\end{array}$ \\
\hline $\begin{array}{l}\text { Consumer-community } ® \text { Community } \\
\text { participation } ® \text { Information sharing }\end{array}$ & 0.2546896 & 0.3310430 & $43.48 \%$ & Partial \\
\hline $\begin{array}{c}\text { Consumer-platform }{ }^{\circledR} \\
\text { Community participation } \AA \text { Information } \\
\text { sharing }\end{array}$ & 0.2258404 & 0.4232920 & $34.79 \%$ & Partial \\
\hline $\begin{array}{c}\text { Consumer-community } ® \text { Reciprocity } ® \\
\text { Information sharing }\end{array}$ & 0.3339277 & 0.2502610 & $57.16 \%$ & Partial \\
\hline $\begin{array}{l}\text { Consumer-platform }{ }^{\circledR} \\
\text { Reciprocity }{ }^{\circledR} \\
\text { Information sharing }\end{array}$ & 0.2826689 & 0.3676670 & $43.47 \%$ & Partial \\
\hline
\end{tabular}

this meant that consumers were satisfied with or preferred such products or brands. However, not all consumers were willing to actively participate in the activities of the community platform. A strong sense of identity and a high degree of involvement with the community were necessary to instigate active participation in community activities by consumers; thus, this study inferred that the relationship between consumers and a product/brand did not significantly affect community participation. 
The reasons hypothesis H3a was not supported were as follows. First, even if consumers had a satisfactory relationship with the community, it was not easy for consumers to share information. Therefore, if enterprises could leverage other factors (e.g., trust, familiarity, cognition, and closeness) to enhance consumers' sense of belonging through opinion exchanges or activities, this could encourage consumers to share information with members of the community. Second, consumers primarily used the community to obtain useful information (e.g., asking questions or asking for help from community members). Although consumers maintained a favorable relationship with the community, consumers' willingness to share information was reduced if they did not perceive some benefit, perceived high risk, or did not completely trust the community after sharing information with the community. The reasons $\mathrm{H} 3 \mathrm{c}$ was not supported were as follows. First, consumers used the platform to search for useful information, and even if consumers were satisfied with the platform and continued to use it, the use entailed information acquisition rather than information sharing. Second, if consumers were unclear about the targets or problems of information sharing, this reduced their intention to share information. Therefore, if the platform incorporated multiinteraction functions to stimulate consumer participation in the discussion, this might encourage consumers to share information.

\section{CONTRIBUTIONS, IMPLICATIONS, LIMITATIONS AND FUTURE RESEARCH}

\subsection{Findings}

According to the aforementioned discussion, this study includes the following critical findings. The first finding pertains to the roles of consumer-community and consumer-platform as community participation and reciprocity critical boosters of the research model. In previous studies, the roles of consumer-community and consumer-platform as antecedents of community participation and reciprocity have received only limited attention in the field of social commerce (Chan \& $\mathrm{Li}, 2010$; Chen et al., 2015; Hajli et al., 2015; Khan, 2017; Pai \& Tsai, 2016). According to research results presented in this study, these roles would become clearer as it would appear that enterprises have to provide appropriate community activities and create opportunities for consumers to communicate with other community members frequently, gain useful information through the community, and even receive encouragement and support from community members (Chan \& Li, 2010; Yu et al., 2018). By implementing suitable measures, consumers' reciprocal attitude can be improved; consequently, consumers would perceive membership in the community as being beneficial and regard reciprocity as their obligation and responsibility. Besides, the effect of consumer-platform also shows a much stronger impact on community participation and reciprocity than consumer-community has shown. The reason why the important motivation for consumers to continuously join in social networks such as social identification, or social support (Phua et al., 2016; Seol et al., 2016). It is possible that consumers pay attention to service quality, customer experience and trust of social commerce platforms to acquire valuable transaction process (Brakus et al., 2009; Kaewkitipong et al., 2016; Kim $\&$ Park, 2013). The finding implies that enterprises have to build comprehensive and user-friendly social commerce platforms to provide consumers with high-quality services and functions (Liang et al., 2011).

According to Jansen et al. (2011), there is less research focusing on the issue of information sharing for ecommerce purposes, even though lots of previous studies investigated the research topics of social network connections and activities. Besides, Kong et al. (2020) noted that existing studies have not explained what critical factors enable consumers to share information with others within ecommerce platforms. The results of this study indicated that reciprocity and community participation exhibited a significantly positive effect on information sharing. According to the results of the test concerning the mediation effect, reciprocity and community participation also had partial mediation effects on the consumer-community and consumer-platform relationships, respectively (Pai \& Tsai, 2016; Chen et al., 2015; Hajli et al., 2015). As hypothesised, the effect of community participation has 
a much stronger impact on consumers' sharing behavior than previous studies have indicated (Fang et al., 2008; Wu \& Sakuko, 2010). The importance of community participation on social commerce may be a contributing factor. Shin (2013) concluded that social commerce activity is more than merely purchasing. Consumers can take part in the social activities of entertainment, education and information to interact with others. The primary strategy of enterprises should be designing appealing community activities that encourage consumers to share their personal experiences and information. As Liang et al. (2011) suggested, building an amicable virtual environment with sufficient social support and maintaining high quality relationships with consumers and enterprises are the useful tactics to enable consumers to participate in communities of social commerce. Hence, the finding indicates that consumer participate in the community and effectively motivate consumers to share their personal experiences and information.

\subsection{Theoretical Contributions}

The academic contributions of this study are as follows. First, three consumer relationships exhibited direct or indirect effects on consumers' information sharing behavior. The results of this study demonstrated that consumers' attitudes and evaluations of products and brands were the key factors affecting consumers' information sharing. In addition, the consumer-community and consumerplatform relationships had indirect effects on information sharing behavior through community participation and reciprocity (Pai \& Tsai, 2016; Chen et al., 2015; Hajli et al., 2015). Therefore, enterprises should value consumers' attitudes and ideas about products and brands and take them as an essential foundation, on the basis of which to engage in continuous research deeply exploring consumers' information sharing behavior in social commerce (Pai \& Tsai, 2016; Shang et al., 2017).

For example, Yelp.com is one of the leading social commerce portals that enables members (i.e., Yelper) to retrieve and contribute valuable tourism reviews. In order to increase brand awareness, Yelp asks users to have an account to read reviews and does not allow users to rate a restaurant without writing reviews as well. Yelp allows users to vote on the usefulness of each review. Hence, Yelp designs social networking activities to enhance consumers engagement. Furthermore, maintaining long term relations with Yelpers is an important business strategy, so Yelp encourages Yelpers to become a member of a premium social community (i.e., the Yelp Elite Squad). Yelpers can interact with each other to share interests and opinions and take part in exclusive events in the community. Yelpers have high intention to continuously contribute quality reviews with high loyalty.

Second, community participation directly affects consumers' information sharing behavior, and the consumer-community and consumer-platform relationships indirectly affect information sharing behavior through community participation. To our knowledge, other research did not deeply explore what influenced consumers' community participation. However, this study determined that in the social commerce environment how to design a platform to induce consumers to participate in the community should be a topic that enterprises pay attention to. Enterprises should provide opportunities for consumers to participate in community activities to narrow the distance between the enterprises and consumers, creating a deeper and stronger connection between them (Grant and Preston, 2018). Specifically, enterprises should increase the degree of consumers' involvement in the community to boost their information sharing behavior (Habibi et al., 2014; Fu et al., 2015; Zhang et al., 2017).

Third, in social commerce, reciprocity is one of the crucial factors affecting consumers' information sharing behavior. The three consumer relationships proposed in this study all positively affected reciprocity, and reciprocity directly affected information sharing behavior. Reciprocity is also a mediator variable. The consumer-community and consumer-platform relationships indirectly affected information sharing behavior through reciprocity. Most other studies explored the effect of reciprocity on knowledge sharing but did not closely examine how it influenced consumer behavior in social commerce. Therefore, in the domain of social commerce research, reciprocity is a key factor that should be explored further. 


\subsection{Managerial Implications}

This study provides valuable guidelines for businesses. First, community participation is an essential factor in social commerce. Enterprises should encourage consumers to participate in the community and value community communication (Laroche et al., 2012; Seol et al., 2016). Enterprises can invite consumers to participate in product production (Chang \& Chuang, 2011). Interactive brand designing activities can improve the connection between the enterprise and consumers and motivate consumers to deeply participate in the product and brand community (Zhang et al., 2018; Zhu et al., 2016). These participatory activities can lead consumers to explore the characteristics and stories of products and brands. These activities can also generate positive consumer evaluations and establish product or brand loyalty, creating a sense of belonging in the community among consumers (Wu \& Lin, 2016; Zhang et al., 2016). As consumers become more active in community activities, they gain a stronger willingness to share their experiences and opinions regarding products and brands in the community (Hashim \& Tam, 2015; Chung et al., 2016).

Second, the consumer-product/brand relationship directly affects information sharing behavior; thus, enterprises should pay attention to consumers' attitudes towards products and brands and improve levels of product and service satisfaction to build brand loyalty. Enterprises should also invite consumers to discuss products and brands and effectively respond to consumers' questions, paying attention to consumers' feedback; these measures would encourage consumers to positively evaluate products and brands (Wu \& Lin, 2016). Hence, enterprises must pay more attention to consumers' needs. They should emphasize the value of products and brands and improve communication with consumers by analyzing consumers' demand for products, understanding consumer expectations for products and brands, and creating friendly and useful community platforms (Gecti \& Zengin, 2013; Barnes, 2014; Phua et a., 2015).

Finally, reciprocity is also an essential factor affecting information sharing behavior. Enterprises should establish information exchange norms and systems (Talja, 2002). If enterprises value consumers' reciprocal benefits on the social media platform and establish a norm for information exchange that enhances consumers' information sharing, this would also help consumers obtain the information they need; for example, consumers may obtain useful information or offers by making a certain number of responses (Chung et al., 2016; Liu et al., 2016). Enterprises should establish a reciprocal community platform that provides consumers with a system of feedback and affirmation to improve consumers' perceptions of reciprocity and make consumers feel a responsibility to reciprocate that encourages consumers to share helpful information (Chan \& Li, 2010; Pai \& Tsai, 2016; Moghavvemi et al., 2017).

\subsection{Limitations and Future Research}

This study has the following limitations. First, consumers have numerous channels for sharing information, including ratings, comments, sharing event information, participating in brand events, and recording unboxing review videos; however, these information sharing methods have various characteristics. To explore the most common consumer behavior patterns, this study incorporated all information sharing behavior. Future studies can explore the background and factors that influence specific consumers to select particular information sharing methods. Second, several types of social commerce platforms exist. Various platforms have different operating methods and purposes, including product discussions, group purchasing, and the establishment of personal brands to sell products. Therefore, consumers' attitudes and purposes tend to be different. The common essential factors of the various types of social commerce platforms should be explored. Therefore, this study included all social commerce platforms to explore the factors affecting consumers' information sharing behavior. Future research can focus on the methods that enhance the value and benefits of social commerce and further consider potential factors such as consumer experience, platform technology, and service innovation to improve the research framework. 


\section{REFERENCES}

Algesheimer, R., Dholakia, U. M., \& Herrmann, A. (2005). The social influence of brand community: Evidence from European car clubs. Journal of Marketing, 69(3), 19-34. doi:10.1509/jmkg.69.3.19.66363

Baethge, C., Klier, J., \& Klier, M. (2016). Social commerce-State-of-the-art and future research directions. Electronic Markets, 26(3), 269-290. doi:10.1007/s12525-016-0225-2

Barnes, N. G. (2014). Social commerce emerges as big brands position themselves to turn "follows", "likes" and" pins" into sales. American Journal of Management, 14(4), 11-18.

Blau, P. M. (1964). Exchange and power in social life. Transaction Publishers.

Brakus, J. J., Schmitt, B. H., \& Zarantonello, L. (2009). Brand experience: What is it? how is it measured? does it affect loyalty? Journal of Marketing, 73(3), 52-68. doi:10.1509/jmkg.73.3.052

Chan, K. W., \& Li, S. Y. (2010). Understanding consumer-to-consumer interactions in virtual communities: The salience of reciprocity. Journal of Business Research, 63(9), 1033-1040. doi:10.1016/j.jbusres.2008.08.009

Chang, H. H., \& Chuang, S. (2011). Social capital and individual motivations on knowledge sharing: Participant involvement as a moderator. Information \& Management, 48(1), 9-18. doi:10.1016/j.im.2010.11.001

Chaudhuri, A., \& Holbrook, M. B. (2001). The Chain of Effects from Brand Trust and Brand Affect to Brand Performance: The Role of Brand Loyalty. Journal of Marketing, 65(2), 81-93. doi:10.1509/jmkg.65.2.81.18255

Chen, J., \& Shen, X. (2015). Consumers' decisions in social commerce context: An empirical investigation. Decision Support Systems, 79, 55-64. doi:10.1016/j.dss.2015.07.012

Chen, Y., Wu, J., Peng, L., \& Yeh, R. C. (2015). Consumer benefit creation in online group buying: The social capital and platform synergy effect and the mediating role of participation. Electronic Commerce Research and Applications, 14(6), 499-513. doi:10.1016/j.elerap.2015.07.003

Cheng, R., \& Fang, W. (2015). Blog intention based on fashion involvement and trust. International Journal of Electronic Commerce Studies, 6(1), 19-36. doi:10.7903/ijecs.1390

Cheung, C. M., Lee, M. K., \& Lee, Z. W. (2013). Understanding the continuance intention of knowledge sharing in online communities of practice through the post-knowledge-sharing evaluation processes. Journal of the American Society for Information Science and Technology, 64(7), 1357-1374. doi:10.1002/asi.22854

Choi, J., Yoon, J., Chung, J., Coh, B. Y., \& Lee, J. M. (2020). Social media analytics and business intelligence research: A systematic review. Information Processing \& Management, 57(6), 102279. doi:10.1016/j. ipm.2020.102279

Choshin, M., \& Ghaffari, A. (2017). An investigation of the impact of effective factors on the success of e-commerce in small- and medium-sized companies. Computers in Human Behavior, 66, 67-74. doi:10.1016/j. chb.2016.09.026

Chung, N., Nam, K., \& Koo, C. (2016). Examining information sharing in social networking communities: Applying theories of social capital and attachment. Telematics and Informatics, 33(1), 77-91. doi:10.1016/j. tele.2015.05.005

Chung, W., Mustaine, E., \& Zeng, D. (2020). A computational framework for social-media- based business analytics and knowledge creation: Empirical studies of CyTraSS. Enterprise Information Systems, 1-23. Advance online publication. doi:10.1080/17517575.2020.1827299

Cronbach, L. J. (1951). Coefficient alpha and the internal structure of tests. Psychometrika, 16(3), 297-334. doi:10.1007/BF02310555

Emerson, R. M. (1976). Social exchange theory. Annual Review of Sociology, 2(1), 335-362. doi:10.1146/ annurev.so.02.080176.002003

Erdoğmuş, İ. E., \& Tatar, Ş. B. (2015). Drivers of social commerce through brand engagement. Procedia: Social and Behavioral Sciences, 207, 189-195. doi:10.1016/j.sbspro.2015.10.087 
Esmaeili, L., Mardani, S., Mutallebi, M., \& Golpayegani, S. A. H. (2015). Studying the affecting factors on trust in social commerce. International Journal of Advanced Studies in Computer Science and Engineering, 4(6), 41-46.

Fang, E., Palmatier, R., \& Evans, K. (2008). Influence of customer participation on creating and sharing of new product value. Journal of the Academy of Marketing Science, 36(3), 322-336. doi:10.1007/s11747-007-0082-9

Forman, C., Ghose, A., \& Wiesenfeld, B. (2008). Examining the relationship between reviews and sales: The role of reviewer identity disclosure in electronic markets. Information Systems Research, 19(3), $291-313$. doi:10.1287/isre.1080.0193

Fornell, C., \& Larcker, D. F. (1981). Evaluating structural equation models with unobservable variables and measurement error. JMR, Journal of Marketing Research, 18(1), 39-50. doi:10.1177/002224378101800104

Foth, M., \& Hearn, G. (2007). Networked individualism of urban residents: Discovering the communicative ecology in inner-city apartment buildings. Information Communication and Society, 10(5), 749-772. doi:10.1080/13691180701658095

Fu, J., Ju, P., \& Hsu, C. (2015). Understanding why consumers engage in electronic word-of-mouth communication: Perspectives from theory of planned behavior and justice theory. Electronic Commerce Research and Applications, 14(6), 616-630. doi:10.1016/j.elerap.2015.09.003

Gecti, F., \& Zengin, H. (2013). The relationship between brand trust, brand affect, attitudinal loyalty and behavioral loyalty: A field study towards sports shoe consumers in turkey. International Journal of Marketing Studies, 5(2), 111-119. doi:10.5539/ijms.v5n2p111

Gouldner, A. W. (1960). The norm of reciprocity: A preliminary statement. American Sociological Review, 25(2), 161-178. doi:10.2307/2092623

Grant, S., \& Preston, T. (2019). Using social power and influence to mobilise the supply chain into knowledge sharing: A case in insurance. Information \& Management, 56(5), 625-639. doi:10.1016/j.im.2018.10.004

Gvili, Y., \& Levy, G. (2021). Consumer engagement in sharing brand-related information on social commerce: The roles of culture and experience. Journal of Marketing Communications, 27(1), 53-68. doi:10.1080/1352 7266.2019.1633552

Habibi, M. R., Laroche, M., \& Richard, M. (2014). The roles of brand community and community engagement in building brand trust on social media. Computers in Human Behavior, 37, 152-161. doi:10.1016/j.chb.2014.04.016

Hadji, B., \& Degoulet, P. (2016). Information system end-user satisfaction and continuance intention: A unified modeling approach. Journal of Biomedical Informatics, 61, 185-193. doi:10.1016/j.jbi.2016.03.021 PMID:27033175

Hair, J., Black, W., Babin, B., \& Anderson, R. (2018). Multivariate data analysis (8th ed.). Academic Press.

Hair, J., \& Hult, G. (2016). A primer on partial least squares structural equation modeling (PLS-SEM). Sage Publications.

Hair, J., Hult, T., Ringle, C., \& Sarstedt, M. (2016). A primer on partial least squares structural equation modeling (PLS-SEM) (2nd ed.). SAGE Publications.

Hair, J., Sarstedt, M., Hopkins, L., \& Kuppelwieser, V. G. (2014). Partial least squares structural equation modeling (PLSSEM): An emerging tool in business research. European Business Review, 26(2), $106-121$. doi:10.1108/EBR-10-2013-0128

Hajli, M. (2013). A research framework for social commerce adoption. Information Management \& Computer Security, 21(3), 144-154. doi:10.1108/IMCS-04-2012-0024

Hajli, N., Shanmugam, M., Powell, P., \& Love, P. E. (2015). A study on the continuance participation in on-line communities with social commerce perspective. Technological Forecasting and Social Change, 96, $232-241$. doi:10.1016/j.techfore.2015.03.014

Hajli, N., \& Sims, J. (2015). Social commerce: The transfer of power from sellers to buyers. Technological Forecasting and Social Change, 94, 350-358. doi:10.1016/j.techfore.2015.01.012 
Hajli, N., Sims, J., Zadeh, A. H., \& Richard, M. (2017). A social commerce investigation of the role of trust in a social networking site on purchase intentions. Journal of Business Research, 71, 133-141. doi:10.1016/j. jbusres.2016.10.004

Hamari, J., Sjöklint, M., \& Ukkonen, A. (2016). The sharing economy: Why people participate in collaborative consumption. Journal of the Association for Information Science and Technology, 67(9), 2047-2059. doi:10.1002/ asi. 23552

Hansen, P., \& Jarvelin, K. (2005). Collaborative information retrieval in an information-intensive domain. Information Processing \& Management, 41(5), 1101-1119. doi:10.1016/j.ipm.2004.04.016

Hashim, K. F., \& Tan, F. B. (2015). The mediating role of trust and commitment on members' continuous knowledge sharing intention: A commitment-trust theory perspective. International Journal of Information Management, 35(2), 145-151. doi:10.1016/j.ijinfomgt.2014.11.001

Ho, C., \& Wang, Y. (2015). Re-purchase intentions and virtual customer relationships on social media brand community. Human-Centric Computing and Information Sciences, 5(18), 1-16. doi:10.1186/s13673-015-0038-x

Homans, G. C. (1958). Social behavior as exchange. American Journal of Sociology, 63(6), 597-606. doi: $10.1086 / 222355$

Hsu, M. H., \& Chang, C. M. (2014). Examining interpersonal trust as a facilitator and uncertainty as an inhibitor of intra-organisational knowledge sharing. Information Systems Journal, 24(2), 119-142. doi:10.1111/isj.12000

Hwang, S., \& Kim, S. (2018). Does mIM experience affect satisfaction with and loyalty toward O2O services? Computers in Human Behavior, 82, 70-80. doi:10.1016/j.chb.2017.12.044

Jansen, B. J., Sobel, K., \& Cook, G. (2011). Classifying ecommerce information sharing behaviour by youths on social networking sites. Journal of Information Science, 37(2), 120-136. doi:10.1177/0165551510396975

Jiang, H., Luo, Y., \& Kulemeka, O. (2016). Social media engagement as an evaluation barometer: Insights from communication executives. Public Relations Review, 42(4), 679-691. doi:10.1016/j.pubrev.2015.12.004

Kaewkitipong, L., Chen, C. C., \& Ractham, P. (2016). Using social media to enrich information systems field trip experiences: Students' satisfaction and continuance intentions. Computers in Human Behavior, 63, 256-263. doi:10.1016/j.chb.2016.05.030

Khan, M. L. (2017). Social media engagement: What motivates user participation and consumption on YouTube? Computers in Human Behavior, 66, 236-247. doi:10.1016/j.chb.2016.09.024

Kim, A. J., \& Johnson, K. K. (2016). Power of consumers using social media: Examining the influences of brand-related user-generated content on Facebook. Computers in Human Behavior, 58(1), 98-108. doi:10.1016/j. chb.2015.12.047

Kim, S., \& Park, H. (2013). Effects of various characteristics of social commerce (s-commerce) on consumers' trust and trust performance. International Journal of Information Management, 33(2), 318-332. doi:10.1016/j. ijinfomgt.2012.11.006

Kline, R. B. (2016). Methodology in the social sciences. Principles and practice of structural equation modeling (4th ed.). Guilford Press.

Kon, Y., Wang, Y., Hajli, S., \& Featherman, M. (2020). In Sharing Economy We Trust: Examining the Effect of Social and Technical Enablers on Millennials' Trust in Sharing Commerce. Computers in Human Behavior, 108, 105993. doi:10.1016/j.chb.2019.04.017

Kovacevic, N., Abdi, H., \& Beaton, D. (2013). Revisiting PLS Resampling: Comparing Significance Versus Reliability Across Range of Simulations. In H. Abdi, W. Chin, V. E. Vinzi, G. Russolillo, \& L. Trinchera (Eds.), New Perspectives in Partial Least Squares and Related Methods (1st ed., pp. 159-170). Springer Science \& Business Media. doi:10.1007/978-1-4614-8283-3_10

Kwahk, K., \& Park, D. (2016). The effects of network sharing on knowledge-sharing activities and job performance in enterprise social media environments. Computers in Human Behavior, 55, 826-839. doi:10.1016/j. chb.2015.09.044 
Laroche, M., Habibi, M. R., Richard, M., \& Sankaranarayanan, R. (2012). The effects of social media based brand communities on brand community markers, value creation practices, brand trust and brand loyalty. Computers in Human Behavior, 28(5), 1755-1767. doi:10.1016/j.chb.2012.04.016

Liang, T., Ho, Y., Li, Y., \& Turban, E. (2011). What drives social commerce: The role of social support and relationship quality. International Journal of Electronic Commerce, 16(2), 69-90. doi:10.2753/JEC10864415160204

Liang, T., \& Turban, E. (2011). Introduction to the special issue social commerce: A research framework for social commerce. International Journal of Electronic Commerce, 16(2), 5-14. doi:10.2753/JEC1086-4415160201

Lin, X., Featherman, M., \& Sarker, S. (2016). Understanding factors affecting users' social networking site continuance: A gender difference perspective. Information \& Management, 54(3), 383-395. doi:10.1016/j. im.2016.09.004

Liu, L., Cheung, C. M., \& Lee, M. K. (2016). An empirical investigation of information sharing behavior on social commerce sites. International Journal of Information Management, 36(5), 686-699. doi:10.1016/j. ijinfomgt.2016.03.013

Lowry, P. B., \& Gaskin, J. (2014). Partial least squares (PLS) structural equation modeling (SEM) for building and testing behavioral causal theory: When to choose it and how to use it. IEEE Transactions on Professional Communication, 57(2), 123-146. doi:10.1109/TPC.2014.2312452

Maria, E. D., \& Finotto, V. (2008). Communities of consumption and made in Italy. Industry and Innovation, 15(2), 179-197. doi:10.1080/13662710801954583

Moghavvemi, S., Sharabati, M., Paramanathan, T., \& Rahin, N. M. (2017). The impact of perceived enjoyment, perceived reciprocal benefits and knowledge power on students' knowledge sharing through Facebook. International Journal of Management Education, 15(1), 1-12. doi:10.1016/j.ijme.2016.11.002

Nakayama, M., \& Wan, Y. (2019). The cultural impact on social commerce: A sentiment analysis on Yelp ethnic restaurant reviews. Information \& Management, 56(2), 271-279. doi:10.1016/j.im.2018.09.004

Pai, P., \& Tsai, H. (2016). Reciprocity norms and information-sharing behavior in online consumption communities: An empirical investigation of antecedents and moderators. Information \& Management, 53(1), 38-52. doi:10.1016/j.im.2015.08.002

Phillips, F. (2011). The state of technological and social change: Impressions. Technological Forecasting and Social Change, 78(6), 1072-1078. doi:10.1016/j.techfore.2011.03.020

Phua, J., Jin, S. V., \& Kim, J. (2016). Gratifications of Using Facebook, Twitter, Instagram, or Snapchat to Follow Brands: The Moderating Effect of Social Comparison, Trust, Tie Strength, and Network Homophily on Brand Identification, Brand Engagement, Brand Commitment, and Membership Intention. Telematics and Informatics, 34(1), 412-424. doi:10.1016/j.tele.2016.06.004

Qin, L., \& Kong, S. (2015). Perceived helpfulness, perceived trustworthiness, and their impact upon social commerce users' intention to seek shopping recommendations. Journal of Internet Commerce, 14(4), 492-508. doi:10.1080/15332861.2015.1103634

Raetzsch, C. (2015). Innovation through practice: Journalism as a structure of public communication. Journalism Practice, 9(1), 65-77. doi:10.1080/17512786.2014.928466

Rioux, K. S. (2005). Information acquiring-and sharing theory. In K. E. Fisher, S. Erdelez, \& L. Mckechnie (Eds.), Theories of information behavior (pp. 169-172). Information Today Press.

Royo-Vela, M., \& Casamassima, P. (2011). The influence of belonging to virtual brand communities on consumers' affective commitment, satisfaction and word-of-mouth advertising: The ZARA case. Online Information Review, 35(4), 517-542. doi:10.1108/14684521111161918

Schultz, R. J., Schwepker, C. H. Jr, \& Good, D. J. (2012). Social media usage: An investigation of B2B salespeople. American Journal of Business, 27(2), 174-194. doi:10.1108/19355181211274460

Seol, S., Lee, H., Yu, J., \& Zo, H. (2016). Continuance usage of corporate SNS pages: A communicative ecology perspective. Information \& Management, 53(6), 740-751. doi:10.1016/j.im.2016.02.010 
Shang, S. S., Wu, Y., \& Li, E. Y. (2007). Field effects of social media platforms on information-sharing continuance: Do reach and richness matter? Information \& Management, 54(2), 241-255. doi:10.1016/j. im.2016.06.008

Siau, K., \& Erickson, J. (2011). The rise of social commerce. Journal of Database Management, 22, 1-7.

Sivarajah, U., Irani, Z., Gupta, S., \& Mahroof, K. (2020). Role of big data and social media analytics for business to business sustainability: A participatory web context. Industrial Marketing Management, 86, 63-179. doi:10.1016/j.indmarman.2019.04.005

Smith, A. N., Fischer, E., \& Yongiian, C. (2012). How does brand-related user-generated content differ across YouTube, Facebook, and Twitter? Journal of Interactive Marketing, 26(2), 102-113. doi:10.1016/j. intmar.2012.01.002

Stephen, A. T., \& Toubia, O. (2010). Deriving value from social commerce networks. JMR, Journal of Marketing Research, 47(2), 215-228. doi:10.1509/jmkr.47.2.215

Tajvidi, M., Richard, M.-O., Wang, Y., \& Hajli, N. (2020). Brand co-creation through social commerce information sharing: The role of social media. Journal of Business Research, 121, 476-486. doi:10.1016/j.jbusres.2018.06.008

Talja, S. (2002). Information sharing in academic communities: Types and levels of collaboration in information seeking and use. New Review of Information Behavior Research, 3(1), 143-159.

Tsai, H., \& Pai, P. (2013). Explaining members' proactive participation in virtual communities. International Journal of Human-Computer Studies, 71(4), 475-491. doi:10.1016/j.ijhcs.2012.12.002

Wan, X., \& Chen, J. (2019). The relationship between platform choice and supplier's efficiency- evidence from China's online to offline (O2O) e-commerce platforms. Electronic Markets, 29(2), 153-166. doi:10.1007/ s12525-017-0280-3

Wang, Y., \& Yu, C. (2017). Social interaction-based consumer decision-making model in social commerce: The role of word of mouth and observational learning. International Journal of Information Management, 37(3), 179-189. doi:10.1016/j.jinfomgt.2015.11.005

Wasko, M. M., \& Faraj, S. (2005). Why should I share? examining social capital and knowledge contribution in electronic networks of practice. Management Information Systems Quarterly, 29(1), 35-57. doi:10.2307/25148667

Williams, M., \& Hodges, N. (2016). Are sponsored blog posts a good thing? exploring the role of authenticity in the fashion blogosphere. Celebrating america's pastimes: Baseball, hot dogs, apple pie and marketing? Springer.

Wong, K.K.K. (2013). Partial least squares structural equation modeling (PLS-SEM) techniques using SmartPLS. Marketing Bulletin, 24(1), 1-32.

Wu, P. H., \& Lin, C. P. (2016). Learning to foresee the effects of social identity complexity and need for social approval on technology brand loyalty. Technological Forecasting and Social Change, 111, 188-197. doi:10.1016/j. techfore.2016.06.028

Wu, W. Y., \& Sukoco, B. M. (2010). Why should I share? examining consumers' motives and trust on knowledge sharing. Computing and Information Systems, 50(4), 11-19.

Yadav, M. S., de Valck, K., Hennig-Thurau, T., Hoffman, D. L., \& Spann, M. (2013). Social commerce: A contingency framework for assessing marketing potential. Journal of Interactive Marketing, 27(4), 311-323. doi:10.1016/j.intmar.2013.09.001

Yang, C., Huang, Y., Yang, K. H., \& Lee, S. (2014). Marketing strategy on social commerce based upon marketing mix. SOP Transactions on Marketing Research, 1(1), 62-76. doi:10.15764/MR.2014.01006

Yang, D., \& Fryxell, G. (2009). Brand Positioning and AntiCounterfeiting Effectiveness: A Study of Managers' Perceptions of Foreign Brands in China. Management International Review, 49, 759-779. doi:10.1007/s11575009-0019-2

Yi, Y., \& Gong, T. (2009). An integrated model of customer social exchange relationship: The moderating role of customer experience. Service Industries Journal, 29(11), 1513-152. doi:10.1080/02642060902793474 
Yoo, C. W., Kim, Y. J., \& Sanders, G. L. (2015). The impact of interactivity of electronic word of mouth systems and E-Quality on decision support in the context of the e-marketplace. Information \& Management, 52(4), 496-505. doi:10.1016/j.im.2015.03.001

Yu, X., Lan, Y., \& Zhao, R. (2018). Cooperation royalty contract design in research and development alliances: Help vs. knowledge-sharing. European Journal of Operational Research, 268(2), 740-754. doi:10.1016/j. ejor.2018.01.053

Yuan, D., Lin, Z., \& Zhuo, R. (2016). What drives consumer knowledge sharing in online travel communities?: Personal attributes or e-service factors? Computers in Human Behavior, 63, 68-74. doi:10.1016/j.chb.2016.05.019

Zhang, K. Z. K., Benyoucef, M., \& Zhao, S. J. (2016). Building brand loyalty in social commerce: The case of brand microblogs. Electronic Commerce Research and Applications, 15, 14-25. doi:10.1016/j.elerap.2015.12.001

Zhang, M., Guo, L., Hu, M., \& Liu, W. (2017). Influence of customer engagement with company social networks on stickiness: Mediating effect of customer value creation. International Journal of Information Management, 37(3), 229-240. doi:10.1016/j.jinfomgt.2016.04.010

Zhang, P., Zhou, L., \& Zimmermann, H. (2013). Advances in social commerce research: Guest editors' introduction. Electronic Commerce Research and Applications, 12(4), 221-223. doi:10.1016/j.elerap.2013.04.002

Zhu, D. H., Sun, H., \& Chang, Y. P. (2016). Effect of social support on customer satisfaction and citizenship behavior in online brand communities: The moderating role of support source. Journal of Retailing and Consumer Services, 31, 287-293. doi:10.1016/j.jretconser.2016.04.013

Yen-Hao Hsieh is an Associate Professor of Department of Business Administration in College of Management at National Formosa University in Taiwan. He received his Ph.D. in Management Information Systems from National Chengchi University. His research interests include Service Science, Service Experience Design, Customer Expectation Management.

Ya-Ting Lo received her Master's degree from Department of Information Management in College of Business and Management at Tamkang University in Taiwan. 